Nova Southeastern University

Florida

\author{
Nova Southeastern University
}

NOVA SOUTHEASTERN

UNIVERSITY

NSUWorks

8-15-2020

\title{
Stay calm and focus on the learning outcomes: Tools for taking biophysical chemistry online
}

\author{
Maria Ballester \\ Nova Southeastern University, mballest@nova.edu \\ Brian L. Van Hoozen Jr. \\ Nova Southeastern University, bvanhooz@nova.edu \\ Arthur Sikora \\ Nova Southeastern University, asikora@nova.edu
}

Follow this and additional works at: https://nsuworks.nova.edu/cnso_chemphys_facarticles

Part of the Chemistry Commons, Education Commons, and the Physics Commons

\section{NSUWorks Citation}

Ballester, M., Van Hoozen, B. L., \& Sikora, A. (2020). Stay calm and focus on the learning outcomes: Tools for taking biophysical chemistry online. Biochemistry and Molecular Biology Education, 48, 504 - 505. https://doi.org/10.1002/bmb.21421. Retrieved from https://nsuworks.nova.edu/ cnso_chemphys_facarticles/288

This Article is brought to you for free and open access by the Department of Chemistry and Physics at NSUWorks. It has been accepted for inclusion in Chemistry and Physics Faculty Articles by an authorized administrator of NSUWorks. For more information, please contact nsuworks@nova.edu. 


\title{
Stay calm and focus on the learning outcomes: Tools for taking biophysical chemistry online
}

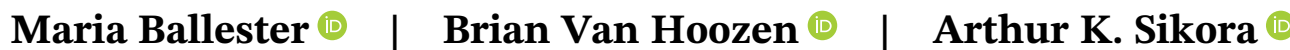

Department of Chemistry and Physics, Nova Southeastern University, Fort Lauderdale, Florida

\section{Correspondence}

Arthur K. Sikora, Department of

Chemistry and Physics, Nova

Southeastern University, Fort Lauderdale, FL, USA.

Email: asikora@nova.edu

\author{
Abstract \\ Course specific learning outcomes are an important tool to define the scope of \\ a course and can be very helpful when designing experiments and assessments. \\ With slight modification, these learning outcomes can serve as a guide when \\ transitioning to the distance learning format especially in courses with a tradi- \\ tional lab. Here we present such an example for the biophysical chemistry \\ course. \\ K E Y W O R D S \\ biophysical methods, COVID-19, distance learning, learning outcomes
}

Upper level science courses typically require a great deal of hands-on experience. They are designed to build experimental acuity in students through a hands-on approach, highlighting instrumentation and data acquisition. The recent COVID-19 pandemic has forced many universities to run their laboratories online. This has opened up an opportunity to rethink the entire laboratory experience and its learning outcomes. Through a hands-on approach, distance learning laboratories can attempt to build experimental skills by focusing on data analysis, results, and scientific communication.

Biophysical Chemistry, at Nova Southeastern University, is a one semester 3000 level course with associated laboratory. Although most of its learning goals can be rapidly translated to a distance learning format, goal \#6 "Perform experiments with instrumentation to measure and calculate physical properties of materials" must be redesigned to accommodate for the lack of access to a physical lab and specialized instruments. For online delivery, this goal is rewritten as: "Analyze data obtained from various repositories to calculate physical properties of materials and communicate results in clear scientific writing." For example, the "Drug-excipient interactions" experiment was redesigned for distance learning following goal \#6. In this lab, students detect incompatibilities between a drug and an excipient through thermal analysis techniques. ${ }^{1-4}$ After a short introduction to the relevant techniques, groups of 3 to 4 members are given previously collected data. They are asked to analyze the data for drug stability, thermal behavior of the binary mixtures (drug-excipient), and compare the drug-excipient data with the one from the drug and excipients alone. Finally, groups write a report that is peer-reviewed by their classmates. The experimental procedure and assessment design was guided by these two learning outcomes: (a) Analyze drug-excipient interactions on the chemical level, and (b) Describe the thermal analysis instrumentation and software.

The task of designing effective learning outcomes, to articulate and solidify anticipated student gains out of any course, can be very difficult even under normal circumstances. Nonetheless, many tools are currently available in previously published frameworks. ${ }^{5-9}$ For example, Pelaez et al. ${ }^{5}$ breaks down the seven areas of competency for biology students, while Irby et al. ${ }^{6-7}$ publications detail the development of specific ALOs for a semester long research-based biochemistry curriculum. ${ }^{10}$ CURE based curricula, like the BASIL project represent a very robust method to teach complex scientific topics. ${ }^{11-12}$ The frameworks described in this paper served to guide the development of our learning outcomes. Moreover, the principles applied to our specific case can also be applied to any distance learning STEM course.

Current events have made the shift to distance learning a necessity for many universities, it has become clear 
that these teaching methods will only become more prevalent in the near future. Therefore, maintaining the quality and rigor of upper level science courses will require a thoughtful translation of current learning outcomes to the distance learning format. This is not only sensible, but it is essential if we are to adapt to this changing world.

\section{ORCID}

Maria Ballester (1) https://orcid.org/0000-0001-8842-8463 Brian Van Hoozen (1) https://orcid.org/0000-0002-0343-

3181

Arthur K. Sikora (1) https://orcid.org/0000-0001-6295-9928

\section{REFERENCES}

1. Sims JL, Carreira JA, Carrier DJ, Crabtree SR, Easton L, Hancock SA, et al. A new approach to accelerated drugexcipient compatibility testing. Pharm Dev Technol. 2003;8(2): 119-26. https://doi.org/10.1081/PDT-120018476.

2. Dourado D. Thermal analysis as a useful tool in drug-excipient compatibility studies: the impact in pharmaceuticals products. Biomed J Sci Tech Res. 2019;22(3):16634-36. https://doi.org/10. 26717/BJSTR.2019.22.003745.

3. Robinson JW, Frame ES, Frame ll GM. Thermal Analysis. Undergraduate instrumental analysis. Boca Raton, FL: CRC Press; 2015;1137-1199.

4. Omiya $\mathrm{AH}$. Compatibility of Itopride $\mathrm{HCl}$ with certain formulation excipients. Unique J Pharm Biol Sci. 2013;01(03):68-71.

5. Pelaez N, Anderson T, Gardner SM, et al. The basic competencies of biological experimentation: concept-skill statements. Purdue, IN: PIBERG Instructional Innovation Materials. Paper 4; 2017. http://docs.lib.purdue.edu/pibergiim/4

6. Irby SM, Pelaez NJ, Anderson TR. Anticipated learning outcomes for a biochemistry course-based undergraduate research experience aimed at predicting protein function from structure: implications for assessment design. Biochem Mol Biol Educ. 2018;46:478-92.

7. Irby SM, Pelaez NJ, Anderson TR. How to identify the research abilities instructors anticipate students will develop in a biochemistry course-based undergraduate research experience (CURE). CBE-Life Sci Educ. 2018;17:1-14.

8. Irby SM, Pelaez NJ, Anderson TR. Student perceptions of their gains in course-based undergraduate research abilities identified as the anticipated learning outcomes for a biochemistry CURE. J Chem Educ. 2020;97:55-65.

9. Anderson TR, Rogan JM. Bridging the educational researchteaching practice gap: tools for evaluating the quality of assessment instruments. Biochem Mol Biol Educ. 2010;38:51-7.

10. McDonald AR, Bernstein HJ, Daubner SC, Goodman A, Irby S, Koppe J, et al. BASIL biochemistry curriculum. 1st edn, Rochester NY: The BASIL Biochemistry Consortium; 2019. https:// doi.org/10.35071/m89q-fa20.

11. Bell JK, Eckdahl TT, Hecht DA, Killion PJ, Latzer J, Mans TL, et al. CUREs in biochemistry-where we are and where we should go. Biochem Mol Biol Educ. 2017;45:7-12.

12. Dolan EL. Course-based undergraduate research experiences: current knowledge and future directions. Natl Res Counc Comm Pap. Washington, DC: National Research Council; 2016; 1:1-34. http://sites.nationalacademies.org/cs/groups/dbassesite/ documents/webpage/dbasse_177288.pdf.

How to cite this article: Ballester M, Van Hoozen B, Sikora AK. Stay calm and focus on the learning outcomes: Tools for taking biophysical chemistry online. Biochem Mol Biol Educ. 2020;48: 504-505. https://doi.org/10.1002/bmb.21421 